\title{
LA VILLA HISPANOÁRABE: ORIENTE EN EL TIBIDABO HISPANOARABIC VILLA: THE EAST AT TIBIDABO
}

Clara Beltrán Catalán* Universidad de Barcelona

\section{Resumen}

Este artículo pretende dar a conocer los interiores inéditos de una esplendorosa casa-torre neoárabe situada a las faldas del monte Tibidabo de Barcelona, cuya urbanización se inició en la década de los noventa del siglo XIX gracias al impulso de algunos de los principales miembros de la burguesía barcelonesa. La investigación ha permitido desvelar el nombre de los arquitectos y de algunos de los artífices que participaron en su construcción, y recuperar su historia a través de los trazos dejados por los sucesivos residentes. A su vez, las fotografías antiguas nos han permitido constatar las transformaciones decorativas que ha experimentado el palacete con el paso de los años y las reformas que se han ido realizando en función de la evolución del gusto de los distintos propietarios. Tibidabo.

Palabras clave: Villa Hispanoárabe, eclecticismo, neoárabe, Dupont,

\section{Abstract}

This article tries to present the unkown interiors of a magnificent neoarabic house located on the foothills of Tibidabo Mountain in Barcelona, whose development began in the nineties of the XIX century thanks to the boost of some of the leading members of the Barcelona bourgeoisie. The research has allowed to reveal the name of the architects and some of the artists involved in its construction, and to recover its history through successive residents. At the same time, antique photographs have allowed us to observe the decorative transformations over the years and the refurbishments that have been carried out according to the changing tastes of its various owners.

Keywords: Villa Hispanoárabe, eclecticism, neo-arabic, Dupont, Tibidabo. 
En la calle León XIII número 15 de Barcelona, se alza majestuosa la "Villa Hispanoárabe", una de las primeras casas-torre que se edificaron a los pies del monte Tibidabo.

El presente artículo, centrado en el estudio de este magnífico palacete, constituye uno de los capítulos de una investigación más amplia acerca de la vida y trayectoria profesional del anticuario francés residente en la Barcelona del 1900, Celestino Dupont Mathieu (1859-1940), que vivió en la Villa Hispanoárabe durante la que consideramos la etapa más importante de su carrera (1908c.1922) ${ }^{1}$. Fue en el transcurso de dicha investigación cuando descubrimos sus espectaculares interiores al localizar unas fotografías antiguas en varios archivos de Barcelona, y pudimos comprobar que la casa todavía se hallaba en pie. Gracias a la generosa disposición y atención de los actuales propietarios, hemos tenido la fortuna de acceder a ella y constatar que todavía brillan esplendorosas las estancias que únicamente conocíamos por imágenes en blanco y negro. Las numerosas visitas para examinar sus interiores, combinadas con una ardua investigación archivística y de hemeroteca, nos han permitido llevar a cabo un estudio en profundidad de la misma, que no había sido realizado hasta el presente, y reconstruir su historia y la de sus residentes desde los inicios de su construcción hasta la actualidad ${ }^{2}$.

\section{Los orígenes del emplazamiento: la heredad del Frare Blanc}

La Villa Hispanoárabe se levantó en una parcela del terreno antiguamente conocido como "la heredad del Frare Blanc", situado en el actual distrito de Sarrià-Sant Gervasi. Este distrito pertenecía al municipio de Sant Gervasi de Cassoles, que fue independiente de Barcelona hasta su agregación en 1897 y que, por entonces, apenas estaba urbanizado, destacando únicamente masías desperdigadas y alguna torre de veraneo de la burguesía ${ }^{3}$.

Originalmente los terrenos de dicho municipio eran, en su mayoría, propiedad de la Iglesia. En concreto, la heredad del Frare Blanc pertenecía a los frailes Dominicos, y el origen del nombre se debe a que por ella discurría un torrente que fue bautizado con el nombre de "Torrent del Frare Blanc" en honor al color del hábito de la orden. Su extensión era de "[...] más de 70 mojadas, unos diez millones de palmos, que se extendía desde lo que hoy es el paseo de Sant Gervasi hasta casi la cima del Tibidabo" 4

Tras la Desamortización, los diversos terrenos pasaron paulatinamente a manos de las grandes familias de la burguesía y de las fortunas indianas, que los fueron adquiriendo al Estado ${ }^{5}$. Concretamente, la heredad del Frare Blanc fue comprada por el indiano Francesc Solernou i Vallès (†1839).

A su muerte lo heredó su hijo primogénito, Francesc Solernou Fernández, que en 1841 formó la sociedad "Fons Palmerola i Companyia" junto con Feliu Palmerola, dedicada a la fabricación de productos derivados del algodón. La empresa se disolvió poco tiempo después, y en 1848 Francesc Solernou vendió la 
heredad del Frare Blanc al padre de la esposa de su socio, el indiano y naviero Llorenç Cayol (†1854), que muy probablemente se había encargado del transporte de mercancías de la compañía. Tras el fallecimiento de Llorenç Cayol y el reparto correspondiente de propiedades entre los miembros de la familia, las tierras pasaron a manos de su hija Josefa, esposa del piloto de marina Josep Parés ${ }^{6}$.

En 1872, Josefa Cayol, ya viuda, decidió comenzar a urbanizar el terreno y una de las primeras calles en edificarse fue León XIII, que constituía el eje central de la urbanización. Las casas comenzaron a construirse tras la rectificación de dicho eje y la Villa Hispanoárabe fue una de las primeras en edificarse, a partir de 18937. Sólo unos pocos años después, en 1899, el doctor Salvador Andreu (1841-1928), conocido por sus famosas pastillas para la tos, y la S. A. Tibidabo que él presidía, emprendieron todo el proyecto de urbanización de las faldas y la cima del monte homónimo, que acabó de organizar el territorio y conectarlo con Barcelona con la creación de un tranvía y un funicular, obra del ingeniero Buenaventura Roig y Queralt ${ }^{8}$.

A partir de este momento, esta parte de la ciudad se convirtió en un nuevo foco de atracción residencial de la burguesía, y la cumbre del Tibidabo, en un gran centro de ocio para los barceloneses.

\section{Historia de la casa: promotores, arquitectos $y$ sucesivos propietarios}

Los promotores de la Villa Hispanoárabe fueron el matrimonio formado por Teresa Miguez Borrego (1858-1898), que figura en la documentación como propietaria de la parcela, y el empresario José Yebra Alonso $(\dagger 1899)$. En agosto de 1893 el Ayuntamiento del territorio les otorgó el permiso de obras para edificar la casa, que bautizaron con ese nombre en alusión a su estilo ${ }^{9}$, y que probablemente fue destinada a residencia estival.

Este revival de tintes románticos estaba muy de moda entre la burguesía catalana a pesar de la escasa tradición musulmana en el territorio ${ }^{10}$. El interés por Oriente Próximo se había empezado a gestar en Europa a finales del siglo XVIII y a lo largo del XIX a medida que llegaban relatos de los viajeros, artistas e intelectuales que lo visitaban y, sobre todo, a raíz de la expansión colonial de países como Inglaterra o Francia. Estos países imitaban la arquitectura del territorio conquistado, lo que podía interpretarse como otra forma de apropiación, pero también buscaban evocar el exotismo de lo diferente, un oasis de evasión y fantasía ${ }^{11}$.

En el caso de España, el movimiento romántico dio lugar a que arquitectos, arqueólogos, escritores, pintores e ideólogos, tanto nacionales como extranjeros, se interesaran por el pasado medieval andalusí y pusieran de moda "lo árabe" con un carácter un tanto tópico, reflejándose en las costumbres, modas y formas de vida burguesas ${ }^{12}$. Concretamente en Cataluña, las primeras manifestaciones públicas del interés por el mundo oriental, definido por Mossén Cinto Verdaguer como "lo mon del color i la fantasia"13, se iniciaron a raíz de las campañas en 
Marruecos del general Prim en 1859-60. Dichas campañas fueron vividas como un gran acontecimiento histórico y se siguieron con gran interés y entusiasmo por parte de los catalanes; interés que a nivel artístico se plasmó en los cuadros, dibujos y acuarelas del pintor Mariano Fortuny ${ }^{14}$, cuya obra desempeñó una auténtica función creadora del gusto por lo oriental, y que pasó a impregnar todos los ámbitos artísticos: música, literatura, fotografía $\mathrm{y}$, evidentemente, la arquitectura. ${ }^{15}$

La burguesía, imbuida del romanticismo importado por los primeros viajeros y por las pinturas fortunianas, solicitaba a los arquitectos del momento que construyeran en este estilo sus palacetes privados, algo que no sólo se consideraba un signo de modernidad y apertura a Europa, sino que también satisfacía sus deseos de "exhibicionismo del éxito". Así, en estas suntuosas residencias se reflejaba el afán de presumir de los burgueses enriquecidos a raíz de su participación activa en el desarrollo económico, para los cuales su casa era una especie de extensión de sí mismos y debía reflejar su estatus social ${ }^{16}$. Igualmente era un modo de evocar un universo de exotismo; un oasis hedonista e idílico donde poder refugiarse de la severa moral reinante y de la incertidumbre de un exterior donde la industrialización y mecanización avanzaba a pasos agigantados y amenazaba la estabilidad social ${ }^{17}$. De hecho, muchas de estas casas esconden leyendas acerca de las motivaciones y los promotores que impulsaron su construcción, alimentadas por la literatura romántica, tan en boga en aquella época. La Villa Hispanoárabe también cuenta con su narración fantasiosa, que señala que la mandó construir un sultán, personaje típico y tópico de las obras orientalistas $^{18}$.

Eran numerosos los profesionales -arquitectos, maestros de obras y decoradores- que acudían a satisfacer la creciente demanda de construcciones de este estilo. Tal y como pone de manifiesto José Manuel Rodríguez, que ha estudiado en profundidad el tema:

"[...] sabían adaptarse a cualquier circunstancia o limitación formal. Se trata, en la mayoría de casos, de artistas que conocen las estructuras y el empleo de los materiales, y que mediante el recurso de códigos estilísticos normalizados eran capaces de pasar del neogótico al neomusulmán y viceversa sin ningún problema"19.

Además, contrariamente a lo que pudiera parecer, para los arquitectos era realmente fácil y económico reproducir las complejas decoraciones a través de moldes $^{20}$, algo que ya apuntó Theóphile Gautier en su libro Viaje por España cuando visitó La Alhambra:

"La mayoría de los adornos están hechos con moldes, y repetidos sin gran esfuerzo cuantas veces exige la simetría. Nada más fácil de reproducir exactamente que una sala de la Alhambra; para ello bastaría con sacar un molde de todos los motivos de ornamentación. [...]. Si fuéramos millonarios, uno de nuestros caprichos sería reproducir el patio de los leones en algunos de nuestros parques"21. 
Los principales modelos de referencia de estos arquitectos en sus construcciones neoárabes fueron los monumentos de Al-Andalus, tierra que satisfacía los deseos de escapismo y, al mismo tiempo, permitía a los españoles entrar en contacto con sus propias raíces, sintiéndose herederos de su antiguo prestigio. De todos ellos, no obstante, el monumento "estrella" era la Alhambra, obra cumbre de la arquitectura del reino nazarí, último baluarte árabe en la Península que se convirtió en el arquetipo de lo islámico. Así, la mayoría de edificios neoárabes que se construyeron eran casi exclusivamente neonazaríes ${ }^{22}$.

Para llevar a cabo el proyecto de la Villa Hispanoárabe, sus promotores escogieron a, un por aquel entonces joven arquitecto, Manuel Vega y March (1871-1931), titulado hacía poco tiempo, pero que pronto se convirtió en un profesional de renombre ${ }^{23}$. Frente a una recreación más "arqueológica", que habría implicado reproducir fielmente las formas de los referentes antiguos, Vega y March llevó a cabo una interpretación más libre, fusionando elementos característicos de la arquitectura islámica - que son los predominantes -, con otros detalles que no son propios de este estilo y que se hallan presentes en la decoración de algunas estancias interiores. Por tanto, podemos considerar la "Villa Hispanoárabe" como un ejemplo de arquitectura ecléctica de tendencia neoárabe ${ }^{24}$.

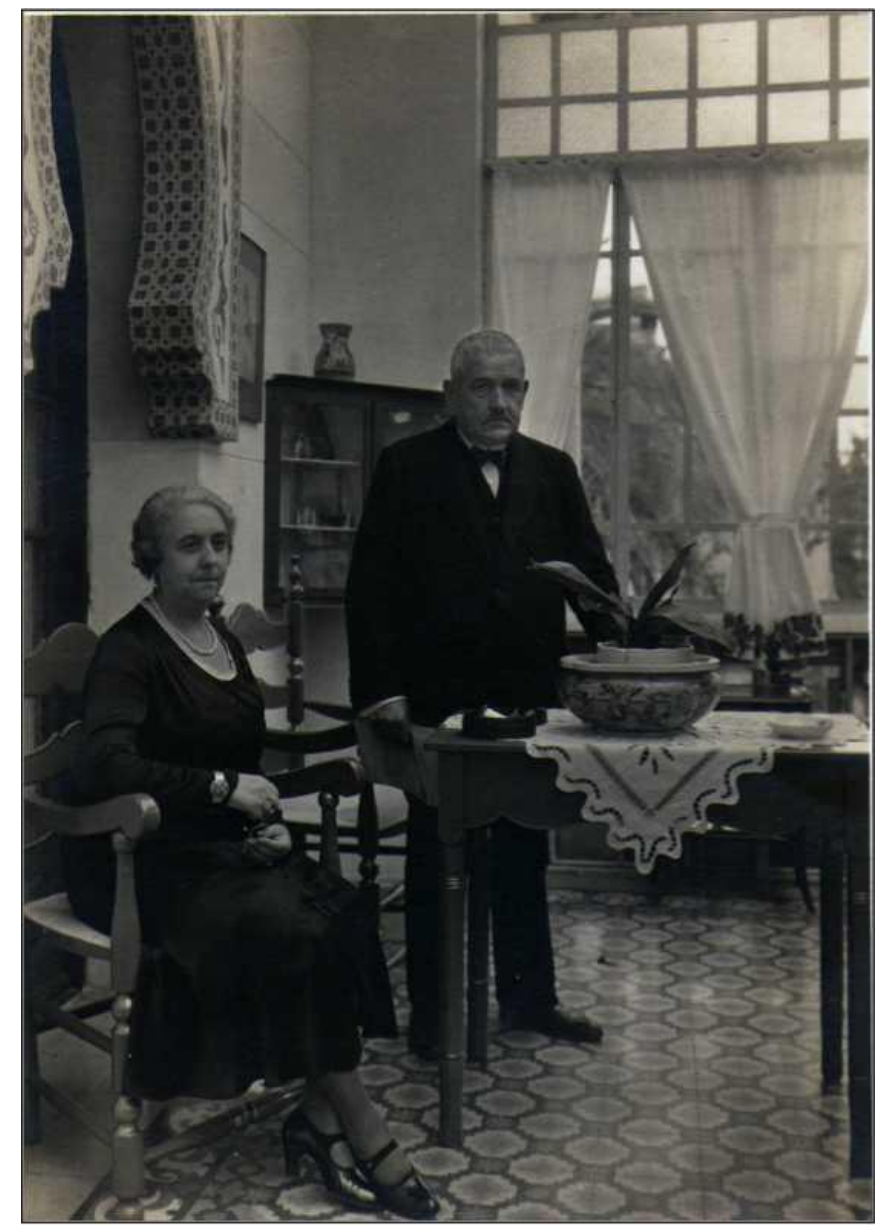

Fig. 1. Celestino Dupont y Josefa Farré en una de las estancias de la casa (c.1930) Fotografía procedente del archivo privado familiar. 
No obstante, los planos diseñados por este arquitecto no se corresponden con la edificación que finalmente se llevó a cabo. La única coincidencia con el proyecto original es la distribución de las estancias alrededor de un patio central, tal y como era habitual en la arquitectura nazaríi ${ }^{25}$.

Sin embargo, ni el Archivo Municipal del Distrito de Sarrià-Sant Gervasi (AMDSG), que conserva los expedientes de las obras llevadas a cabo antes de la anexión de estos municipios a Barcelona, ni el Archivo Municipal Contemporáneo de Barcelona (AMCB), que alberga los de fechas posteriores, cuentan con ningún otro expediente que haga alusión a un cambio de proyecto por su parte. No obstante, no es extraño que los planos no coincidan con el resultado final, pues muchas veces los proyectos se modificaban a medida que la construcción se iba llevando a cabo y no siempre se informaba al Ayuntamiento de tales cambios.

La edificación resultante fue una casa-torre con un mirador adosado a modo de minarete, rodeada de un amplio jardín, compuesta de planta baja, un piso con azotea por cubierta y un sótano. El matrimonio Yebra-Miguez no reparó en gastos para su construcción, y a juzgar por los bellos interiores contó con los mejores artífices del momento en materia de artes decorativas (vidrieras, cerámica, pavimentos, yeserías, etc.)

En noviembre de 1898 Teresa Miguez falleción ${ }^{26}$, dejando en herencia la casa a su marido, José Yebra, que en enero de 1899 la registró como obra nueva. ${ }^{27}$ En diciembre de este último año José Yebra también murió ${ }^{28}$ y la finca fue heredada por el hijo del matrimonio, Sebastián Yebra y Miguez, que tiempo después decidió ponerla en venta.

Fue entonces cuando la adquirió el célebre anticuario Celestino Dupont (1859-1940) y su esposa Josefa Farré Llort (1874-1968) (fig.1), para utilizarla como residencia habitual, haciéndose efectiva la compra el 24 de marzo de $1908^{29}$. Un mes después de su adquisición, Josefa solicitó un permiso al Ayuntamiento para llevar a cabo unas obras de ampliación y reforma en la parte norte de la casa. El encargado de ejecutar el proyecto fue Josep Font y Gumà (1859-1922), destacado arquitecto y coleccionista de cerámica que, muy probablemente, era amigo personal de Dupont, pues en esos años el anticuario ofertaba piezas a la Junta de Museos de Barcelona con mucha frecuencia, y Font y Gumà formaba parte de la comisión gestora de adquisiciones ${ }^{30}$.

La reforma que emprendió Font y Gumà aumentó la superficie de los dormitorios preexistentes en la primera planta a los que, además, se les incorporó lavabos. En el sótano, la zona ampliada se destinó a cocina, cámara para el calorífero, carbonera, bodega y despensa. Por último, en el piso superior se crearon dependencias probablemente destinadas al servicio (fig. 2) ${ }^{31}$.

Dos años después de adquirir la casa, en abril de 1910, Josefa Farré solicitó nuevamente un permiso, esta vez para construir "un cuerpo de edificio" en el ángulo superior izquierdo del jardín, junto a la casa; una edificación independiente de $128 \mathrm{~m}^{2}$ de superficie, que también ejecutó Font y Gumà ${ }^{32}$.

A pesar de que su uso no se especifica en la documentación, podemos deducir que dicho espacio fue habilitado por Dupont para su negocio de compraventa de antigüedades pues, según fuentes familiares, la casa contaba con un 
cuerpo independiente edificado en el jardín donde albergaba las obras de arte y llevaba a cabo sus tratos comerciales.

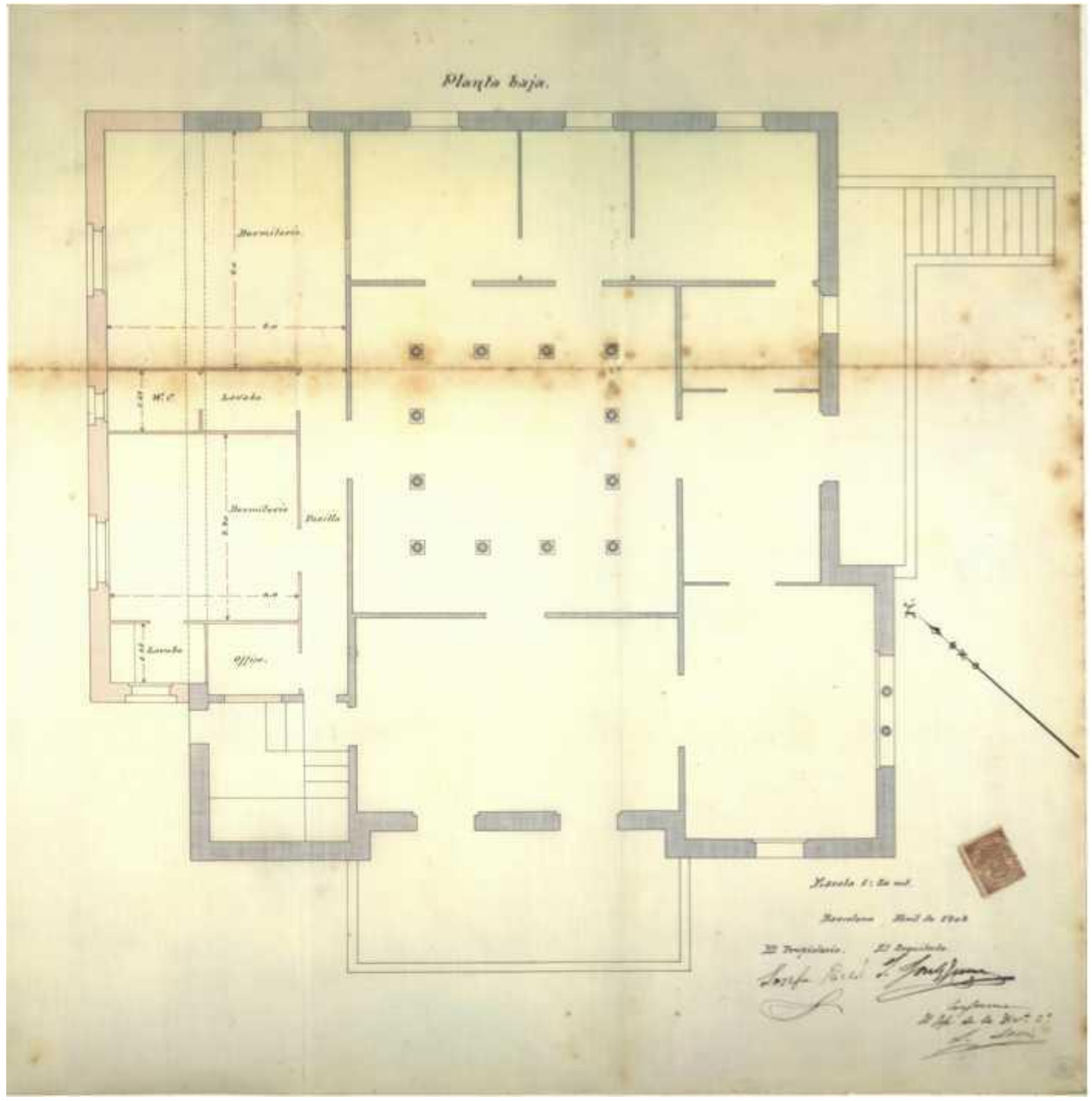

Fig. 2 Plano de la Villa Hispanoárabe y proyecto de ampliación de la planta baja firmado por Josep Font i Gumà. Fuente: AMCB Fo-531/1908.

Celestino Dupont y su familia residieron en la Villa Hispanoárabe hasta principios de los años veinte, cuando decidieron mudarse a Sevilla. En mayo de 1934 segregaron el terreno que ocupaba la finca en dos partes, y vendieron la parcela actual de la casa, de aproximadamente $1000 \mathrm{~m}^{2}$, al matrimonio formado por el pintor andaluz Ramón López Morelló ${ }^{33}$ y su esposa, Victoria Vial Torns ${ }^{34}$. Un anuncio en la prensa de la época nos revela que durante la Guerra Civil la casa se utilizó como hospital: "El pintor López Morelló, tiene instalado en su 
domicilio de la calle de León XIII, número 15, un Hospital de sangre con ocho camas, que pone a disposición de las autoridades. El mencionado Hospital cuenta también con el personal auxiliar para el cuidado de los heridos que puedan confiársele" 35 .

En 1940 la Villa Hispanoárabe fue puesta nuevamente en venta. La adquirieron el ingeniero alemán Hans Breuer Theissen y su esposa, de nacionalidad sueca, Signe Larsson Linberg $(\dagger 1981)$ que, según fuentes orales, habían venido de Alemania huyendo de la Segunda Guerra Mundial. Al fallecer Signe Larsson, y al no tener descendencia, la casa fue heredada por la responsable del servicio, Isabel Aparicio (†2000), y a la muerte de ésta la heredó su hermana Rafaela, que no interesada en la propiedad la puso en venta ese mismo año. La adquirió una empresa constructora, que a su vez la vendió dos años después a los actuales propietarios, un matrimonio formado, curiosamente, por una sueca y un catalán, que reside con sus cuatro hijos ${ }^{36}$.

\section{Fachada e interiores: descripción y análisis}

Como hemos señalado previamente, la casa se compone de planta baja, un piso con azotea, un sótano, y un gran jardín que la rodea. A diferencia de la mayoría de construcciones de la época, que adoptan el estilo neoárabe únicamente con un objetivo ornamental o de "creación de ambientes" sin profundizar en las motivaciones constructivas de este tipo de arquitectura o en su concepción estructural, la "Villa Hispanoárabe" sí que presenta una mayor coherencia con el espíritu de las construcciones islámicas, que se conciben en función del interior, dando a su exterior "una faz sobria cuando no descuidada" 37. Si bien en el caso de este palacete no podemos hablar de aspecto exterior descuidado, sí que es cierto que es más contenido que el de la mayoría de las construcciones neoárabes de la ciudad, repletas de ricos motivos ornamentales a base de esgrafiados o bajorrelieves, fruto de la libre interpretación de tintes románticos de los arquitectos que las llevaron a cabo.

En su fachada principal, las ventanas en forma de arco de herradura apuntado rompen con la monotonía de los paramentos lisos (fig.3). Están decoradas con una cenefa de caligrafía cúfica cincelada en finos bajorrelieves que enmarca cada alfiz, y cada una de ellas cuenta con una reja con la característica estrella de ocho puntas. A la izquierda de la entrada, a su vez, hay un triple ventanal cuyas arcadas descansan sobre dos parteluces con fuste de conglomerado de piedra y capiteles que recuerdan a los de la sala del mihrab de la Mezquita de Córdoba. 
Si por algo llama la atención es por su singular torre-mirador a modo de minarete. Al igual que en la fachada, cuenta con ventanas geminadas de arco de herradura apuntado en cada uno de sus lados, que presentan decoración pictórica de motivos geométricos en el intradós y un alicatado de azulejos bajo el alféizar. Está coronada por una pequeña cúpula escamada con tejas de cerámica vidriada policromada, que proporcionan un toque de plasticidad al conjunto, y rematada por una veleta ${ }^{38}$. La cubierta exterior de la casa es en amplio voladizo, cuyos aleros descansan en modillones de madera con pequeñas molduras ornamentales.

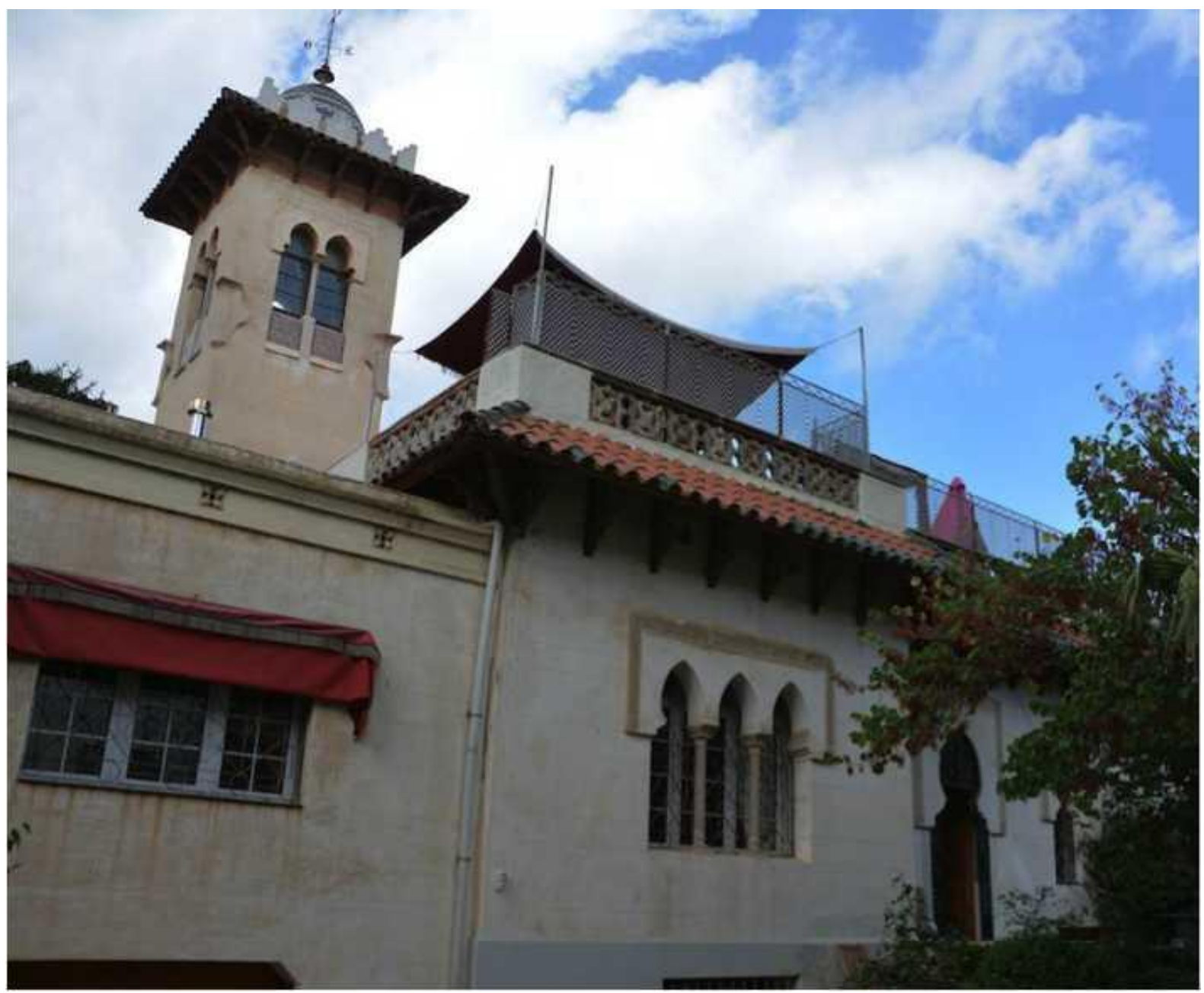

Fig. 3. Fachada principal de la Villa Hispanoárabe (2013) @ Consol Bancells

Los planos de 1908 nos revelan que en la planta baja se encontraban las dependencias de estar, los dormitorios, y los cuartos de baño, funciones que se mantienen en el presente. En el piso superior, donde originalmente creemos que se hallaban las habitaciones del servicio, hay actualmente dormitorios. En el sótano, las estancias antes ocupadas por la cocina, la caldera y la bodega, hoy están destinadas a almacén y labores domésticas. La cocina actualmente se encuentra en el primer piso, ocupando el espacio de un antiguo porche, y se accede a ella a través del salón. La entrada a la vivienda se efectúa a través de una bella puerta de madera maciza de doble hoja con aplicaciones decorativas en bronce, antecedida por una cancela de hierro forjado rematada en forma de arco 
de herradura apuntado, en cuyos huecos se insertan fragmentos de vidrio catedral coloreado. Un pequeño recibidor (fig. 4), en el que destaca el hermoso pavimento de mosaico de gres cerámico, conduce a un esplendoroso patio claramente inspirado en el Patio de los Leones de la Alhambra (fig.8). No obstante, no constituye una reproducción fiel de la joya nazarí, sino una interpretación caprichosa por parte del arquitecto. Así, a diferencia del patio granadino, de forma rectangular, éste tiene planta cuadrada. Tampoco reproduce los arcos de medio punto peraltados y angrelados del patio alhambrista, sino las arcuaciones de mocárabes de los pabellones de sus extremos, con decoración a base yeserías ornamentadas con escritura cúfica, escudos nazaríes con el lema "Sólo Alá es vencedor" y atauriques, que se fusionan en una estrecha unidad.

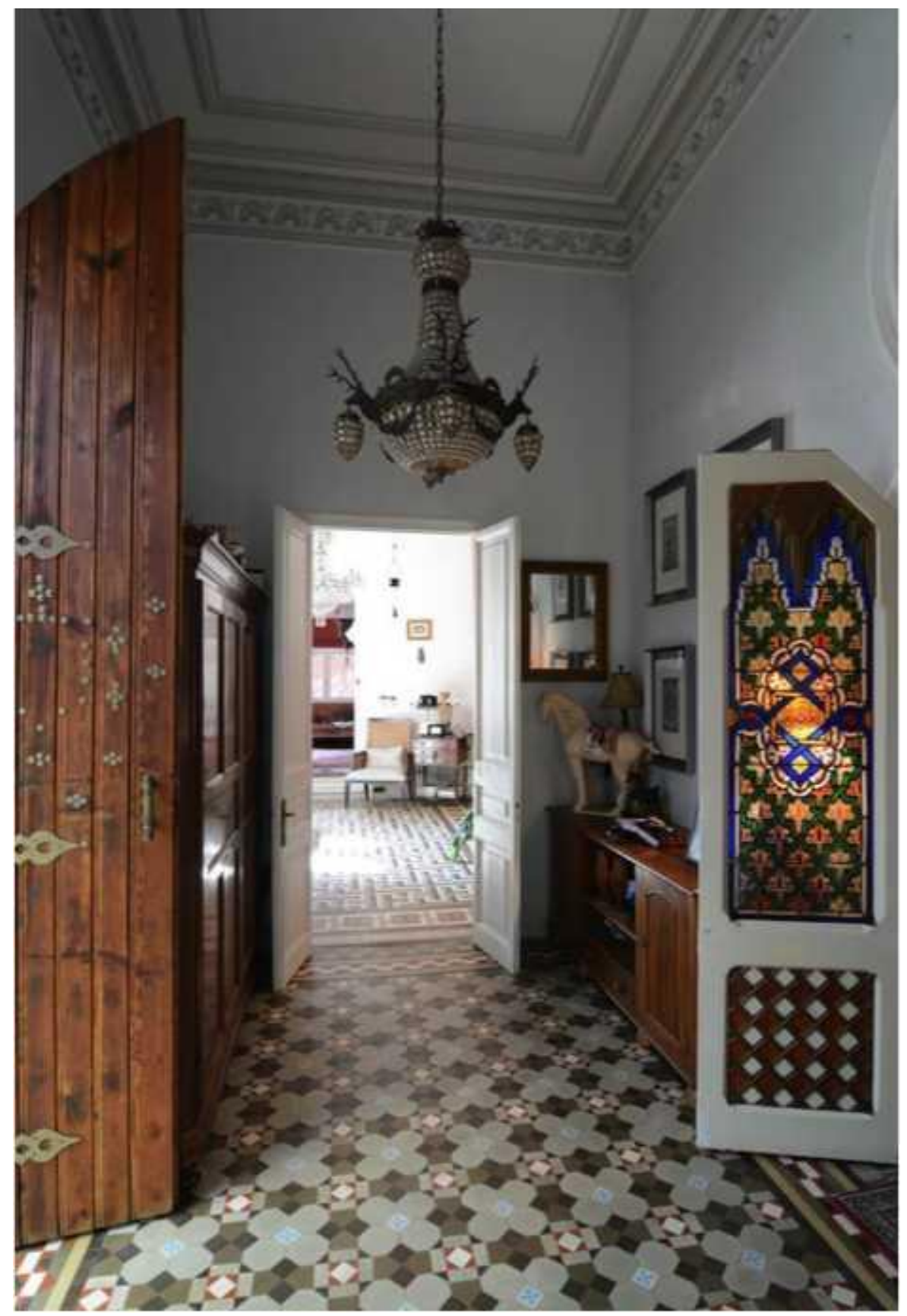

Fig. 4. Recibidor de la Villa Hispanoárabe (2014) C Consol Bancells 
Esta decoración de arabescos se hace extensible al friso que enmarca las paredes y corona el bello zócalo cerámico, formado por azulejos de arista con decoración geométrica y rematado por las características almenas escalonadas. Responde a un diseño típico sevillano del siglo XVI de los que se fabricaban en aquellos momentos en la capital andaluza y se empleaban en la arquitectura regionalista, probablemente fabricado por la casa Mensaque, Rodríguez \& Cía., pues hemos localizado un catálogo en el que se muestra un diseño prácticamente idéntico (figs. 5 y 6$)^{39}$.
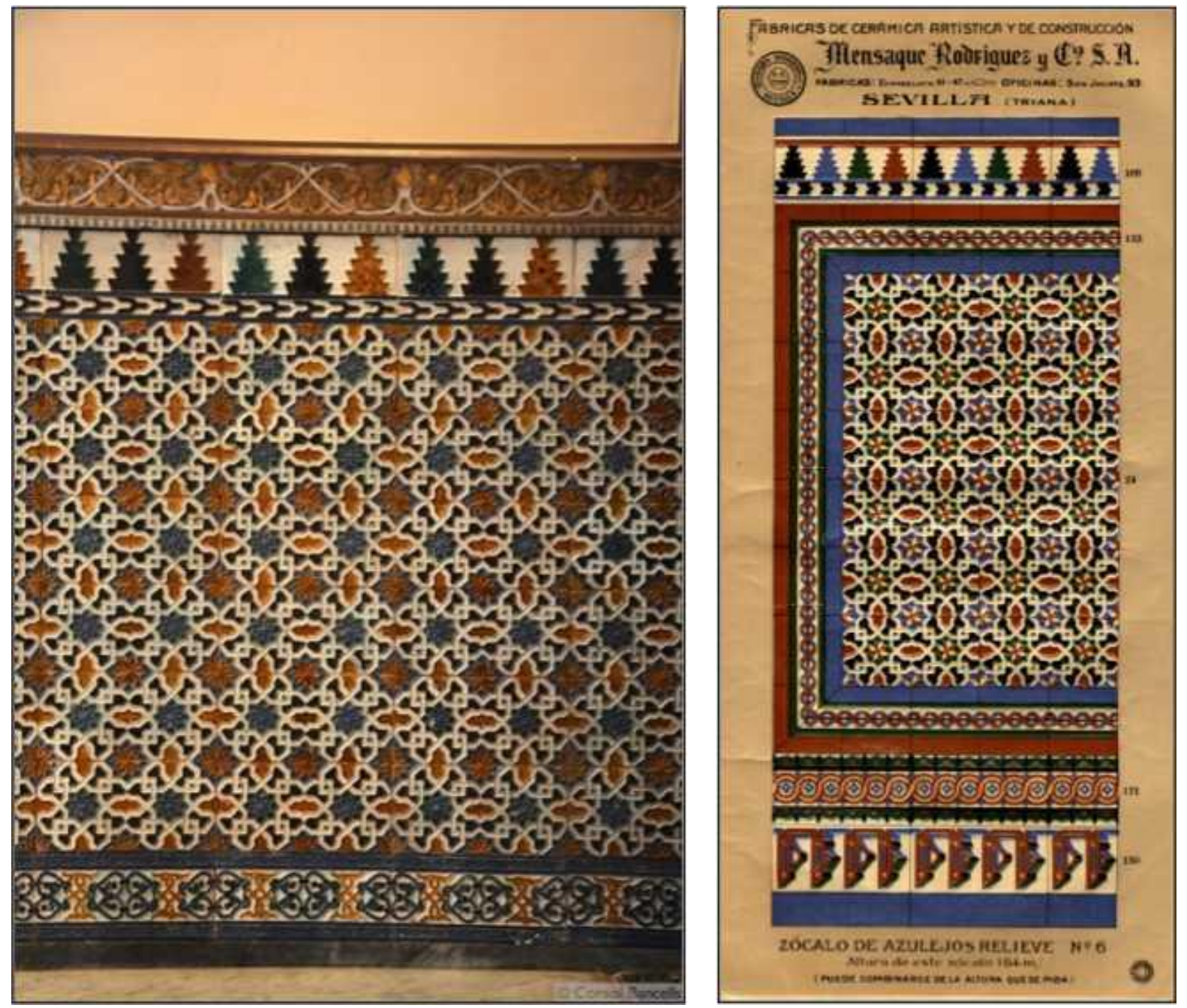

Fig. 5. Zócalo cerámico del patio de la Villa Hispanoárabe (2013) @ Consol Bancells

Fig. 6. Modelo de zócalo diseñado con unos motivos muy semejantes. Fuente: Mensaque, Rodríguez y Cía. S. A. Catálogo de azulejos de serie. Sevilla: [s.f]

Los arcos descansan en estilizadas columnas de mármol con vetas grises, material que también se empleó en el enlosado del suelo, copiando el del patio de los Leones, en el que los alarifes emplearon mármol blanco, piedra natural asociada con la grandiosidad, para dotar de riqueza y suntuosidad al espacio y evocar el poder de sus poseedores. Existen testimonios de algunos viajeros del siglo XVI, como Luis del Mármol, Antonio de Lalaing o Hieronymus Münzer, que 
hicieron alusión a los bellos pavimentos del patio alhambrista; este último señaló: "había muchas losas de mármol de quince pies de longitud por siete u ocho de anchura, e igualmente muchas cuadradas, de diez y once pies. No creo que haya cosa igual en toda Europa" 40 . Sin duda esta sensación de magnificencia que se transmitía a los visitantes del Patio de los Leones era la que se quería igualmente lograr en las construcciones neoárabes de finales del XIX.

Originalmente las yeserías estaban policromadas con los colores primitivos de la Alhambra (rojo, azul y dorado), que Owen Jones recuperó en su tratado arquitectónico del edificio nazarí ${ }^{41}$. Sin embargo, tras la moderna restauración llevada a cabo por los actuales propietarios, se emplearon únicamente los tonos dorados en las yeserías, y los plateados en los pequeños detalles ornamentales. A su vez, no es un patio a cielo abierto como los musulmanes, sino que está cubierto por un riquísimo artesonado de yeso con suntuosas decoraciones a base de motivos vegetales y geométricos policromados en tonos ocres y dorados. Su detalle principal es una estrella de ocho puntas de la que emergen dos aspas y de cuyo centro cuelga una lámpara de araña.

En el centro del patio se aloja una fuente con una taza dodecagonal similar a la de la sala de los Abencerrajes del palacio nazarí. Ilumina el espacio una galería de vidrieras rematadas en arcos de herradura polilobulados, cuyos vidrios reproducen motivos de lacerías de rico colorido, por los que penetra una luz tamizada que sumerge al espectador en un mar de estímulos sensoriales. Las ventanas descansan sobre una cornisa decorada con pechinas que corona los paños que forman las arcadas de mucarnas.

Gracias al hallazgo de antiguas fotografías, sabemos cómo estaba decorado este patio en la época en la que residían tanto los Dupont como sus anteriores propietarios, y también cómo lucía la otra habitación principal de la casa, el salón comedor. Estas imágenes constituyen documentos muy preciados, pues nos permiten comparar el estado original de las estancias con su apariencia actual.

Una de ellas, publicada en la revista La Ilustració Catalana en 190942, nos resulta especialmente interesante, pues no sólo nos muestra el aspecto del patio cuando habitaba la casa Celestino Dupont, sino que también figura la disposición en vitrinas de parte de la rica colección de indumentaria litúrgica que el anticuario atesoraba (fig. 7). Otra imagen anterior, publicada en septiembre de 1901 en la revista Arquitectura y construcción, que dirigía precisamente Manuel Vega y March, arquitecto de la casa, nos permite constatar que originalmente los paramentos del patio presentaban motivos arabizantes, aunque la baja calidad de la fotografía no nos permite determinar si se trataba de pintura mural, esgrafiado o papel de pared (fig.9) ${ }^{43}$. Esta ornamentación no se aprecia en la mencionada imagen de 1909, al estar las paredes cubiertas por las vitrinas colocadas por Dupont. En la actualidad no queda rastro de esta decoración y los paramentos son lisos. Por otro lado, en la imagen de 1909 la fuente central del patio aparecía ocupada por unas plantas, lo que denota que se le otorgaba una funcionalidad meramente ornamental, al igual que en la actualidad, en la que actúa como peana de un busto de Buda. 


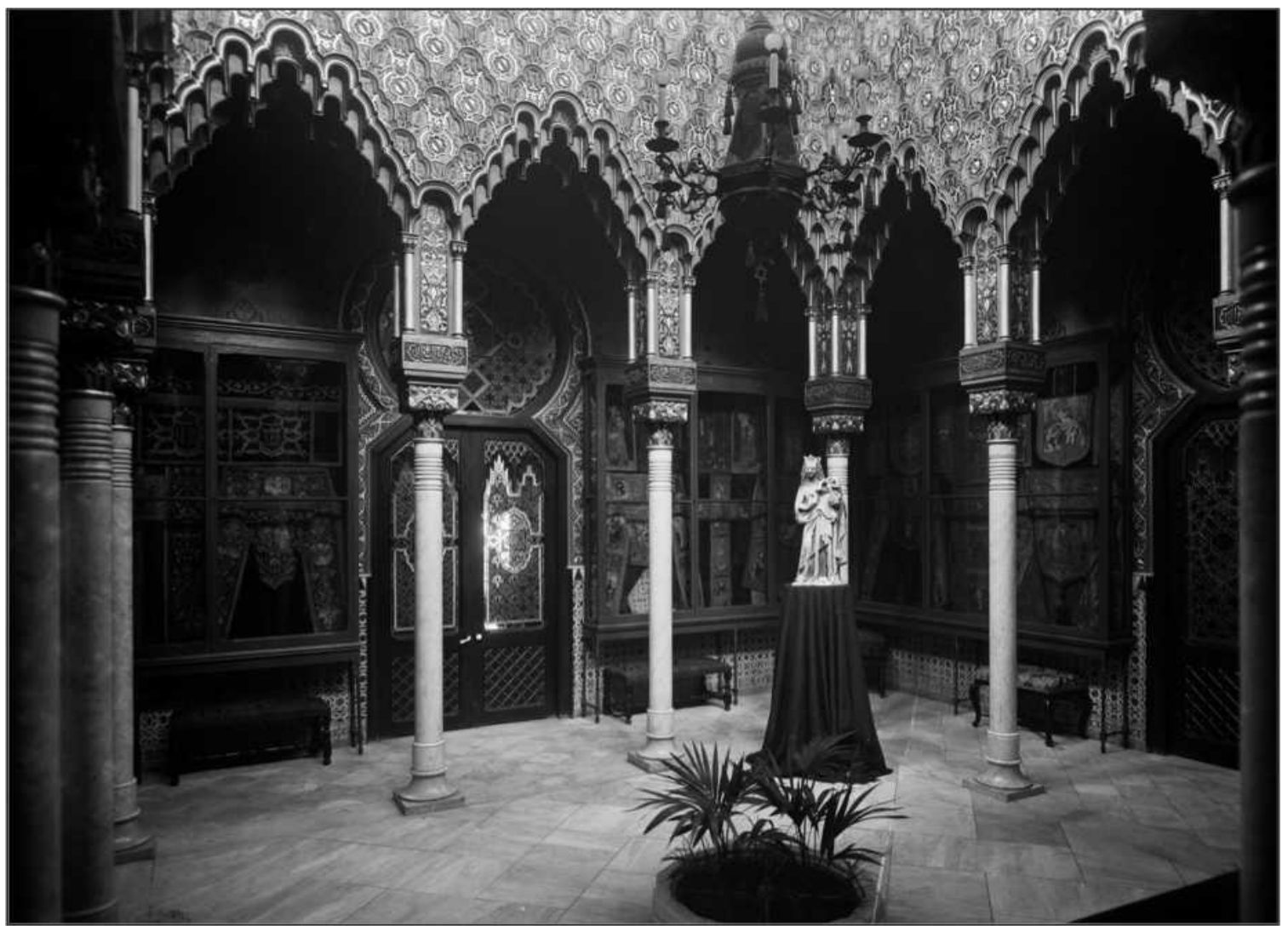

Fig. 7. Patio de la Villa Hispanoárabe, propiedad de Celestino Dupont (1909). (C) Arxiu Mas. Institut Amatller d'Art Hispànic (B-1425).
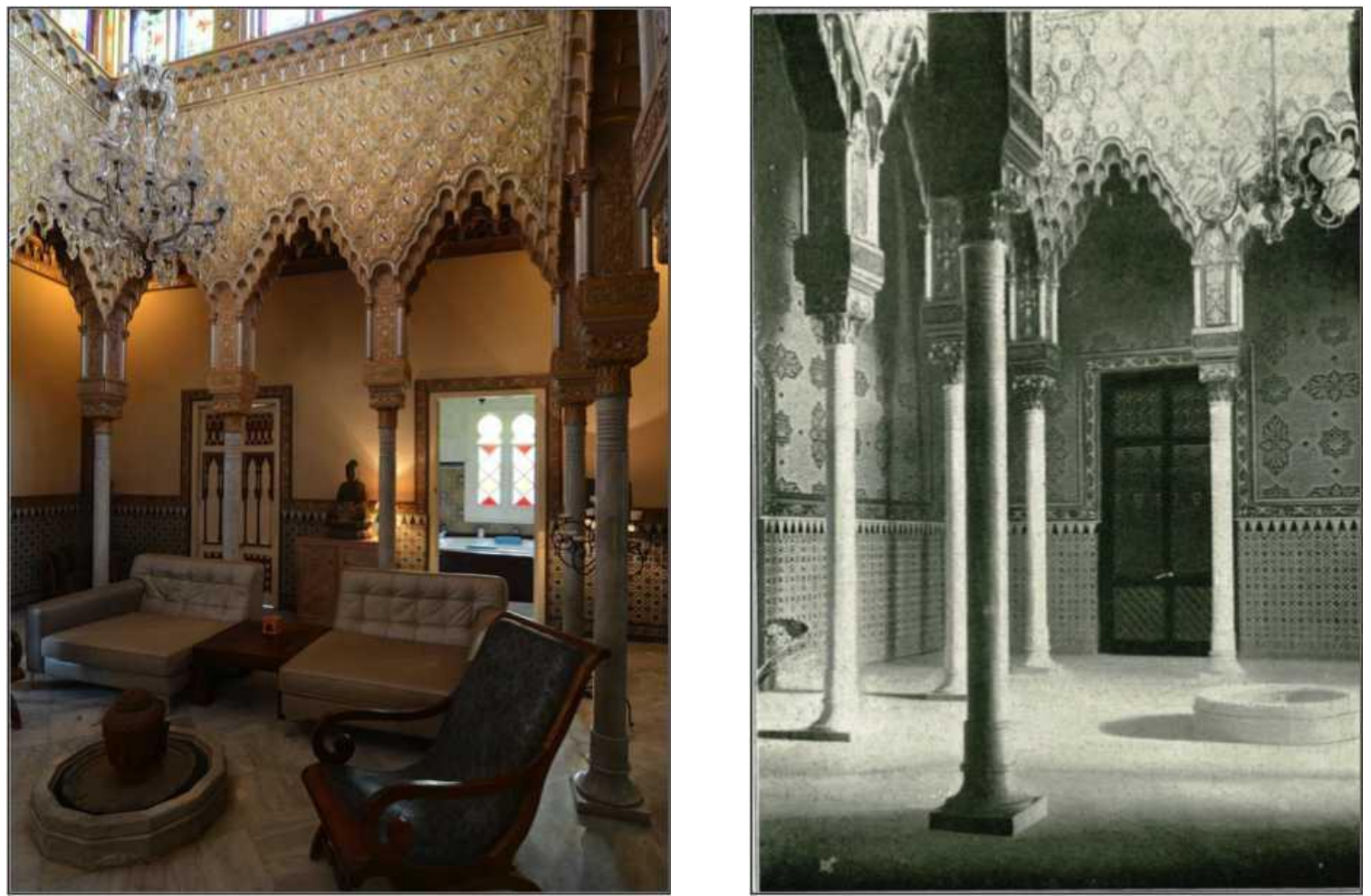

Fig. 8. Patio de la Villa Hispanoárabe (2014) (C) Consol Bancells

Fig. 9. Patio de la Villa Hispanoárabe (1901) Fuente: Arquitectura y Construcción, 8 de septiembre de 1901. 
Contrasta, a su vez, la lámpara de araña que luce actualmente en el patio, con la de estilo árabe de la época de Dupont, y que hoy en día se conserva en la torre-mirador. Curiosamente, en la fotografía de 1901, época en la que vivían los primeros propietarios, este objeto también era diferente: una lámpara de gas de brazos con tulipas de cristal de formas gallonadas en espiral, que contribuía a crear ese ambiente ecléctico en el que la decoración neoárabe se combinaba con muebles de estilos diferentes y elementos de confort y técnicos novedosos. Así, estas lámparas vienen a representar un símbolo a pequeña escala de los gustos de los sucesivos residentes.

En el presente, el patio cuenta con un mobiliario moderno que lo habilita como un espacio "para estar", y contrasta con la función "museística" original que le otorgaba el anticuario Dupont. Sin lugar a dudas, tanto estímulo sensorial impactaría a los visitantes de la casa, que quedarían sumamente perturbados e impresionados ante el ambiente abigarrado, mezcla de exotismo y lujo, que encontrarían al acceder a ella.

Siguiendo el esquema de las casas nazaríes, el patio actúa como espacio distribuidor de las diferentes estancias de esta planta. Se accede a las mismas a través de unas puertas de madera profusamente trabajadas, que originalmente eran oscuras y tras la restauración se lacaron en blanco. Algunas de ellas presentan originales vidrieras emplomadas de intensos colores pintadas con esmaltes que forman motivos arabizantes, en consonancia con el resto de la decoración, y otras cuentan con relieves tallados con formas arquitectónicas islámicas.

El otro espacio destacado de la casa es el gran salón comedor del que, como hemos apuntado, también se ha conservado una antigua fotografía de 1909. Fue publicada, junto con la imagen del patio, en la ya mencionada revista $L a$ Ilustració Catalana, y resulta ilustrativa del gusto de los Dupont, que podemos hacer extensible al de las familias burguesas de fin de siglo (fig.10) ${ }^{44}$.

El mobiliario que lo decoraba entonces se caracterizaba, de acuerdo con la moda de aquel momento, por emplear maderas y tapicerías de tonalidades oscuras, con clavos decorativos, patas rectas y a menudo helicoidales, como se observa, por ejemplo, en la mesa central, así como por la presencia de torneados en cómodas y trinchantes. Así, tal y como señala Leire Rodríguez, "los talleres que fabricaban mobiliario en aquella época reinterpretaron los modelos del Renacimiento, Barroco, Gótico, Luis XV, Luis XVI, Imperio, etc., de forma modernizada y con amplias posibilidades, aplicándolos a una extensa variedad de muebles: desde las antiguas arquillas hasta los recuperados escaños, pasando por los diferentes tipos de mesas, armarios, aparadores, camas o sillería" 45 . 


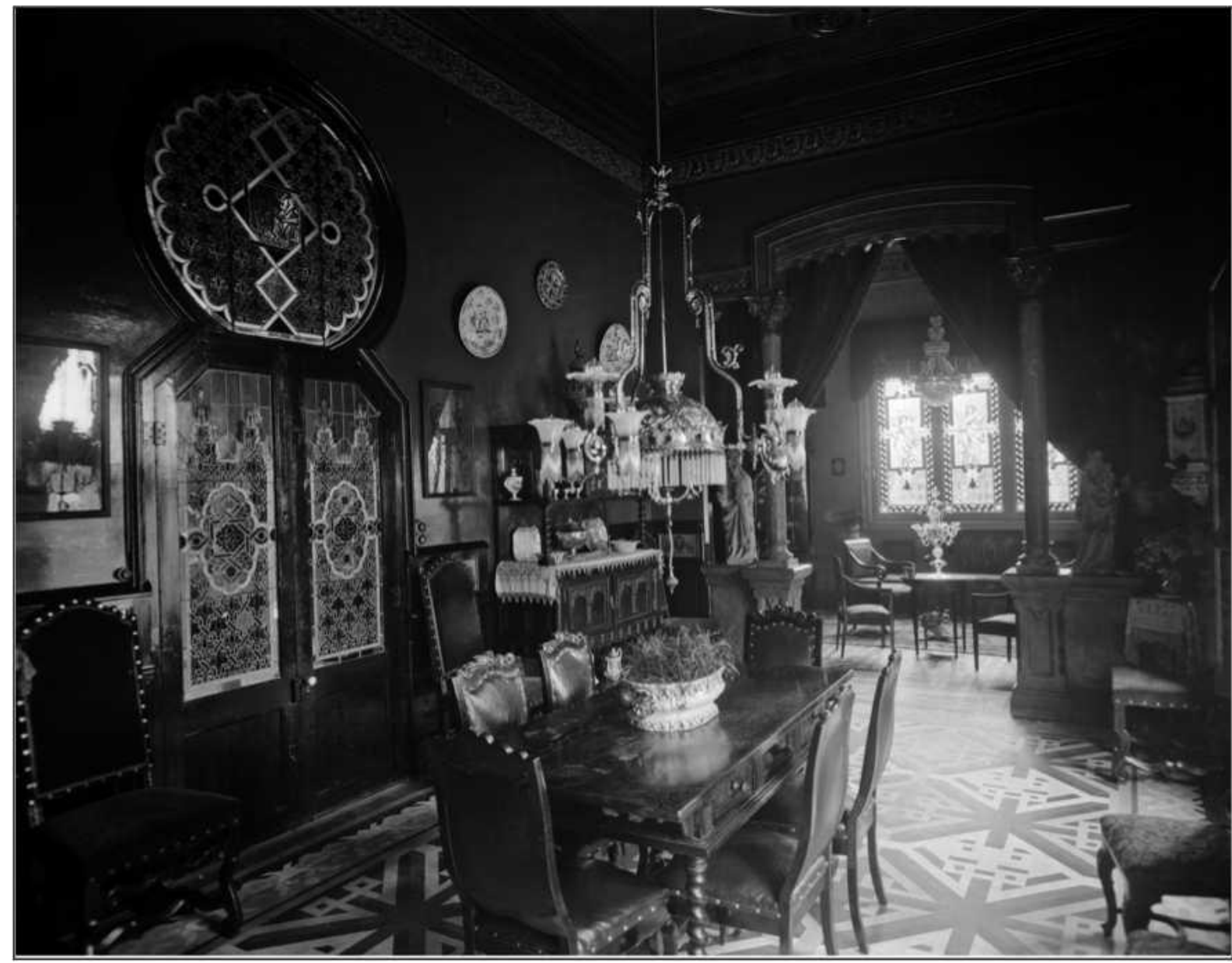

Fig. 10. Comedor de la Villa Hispanoárabe cuando residía Celestino Dupont (1909). CArxiu Mas. Institut Amatller d'Art Hispànic (C-1422).

Todo ello se ve ampliamente ejemplificado en este salón, en el que se conjugan los muebles de estilo Renacimiento francés del país de origen de Dupont, con el exotismo árabe que representa lo español, su segunda patria. Igualmente se observan numerosos objetos de cerámica que denotan la afición del anticuario por estas piezas. Así, por ejemplo, identificamos en la pared platos de cerámica de Alcora y de reflejos dorados. Destaca, a su vez, el centro de mesa y el aguamanil, también de cerámica de Alcora, y en la mesita del fondo, un espectacular candelabro de cristal de Murano.

El techo del salón consiste en un cielo raso de líneas clásicas que contrasta con el llamativo pavimento de mosaico de gres cerámico que simula una alfombra de formas romboidales de intensos colores, y con la triple arcada de medio punto angrelada cuyos arcos extremos son apuntados y de menor tamaño, que conduce a la salita contigua (fig.11). Estas arcadas neoárabes son fruto de una reforma posterior, pues no se observan en la imagen de 1909, en la que vemos que la transición del salón a la salita se realizaba a través de un arco carpanel apoyado sobre dos columnas situadas sobre unos podios de mármol que enmarcaban el acceso $^{46}$. Los fustes de dichas columnas fueron los únicos elementos reaprovechados en la nueva estructura, y pasaron a descansar directamente en el 
pavimento, en el que a día de hoy todavía se aprecian las huellas de los antiguos pedestales que los sustentaban.

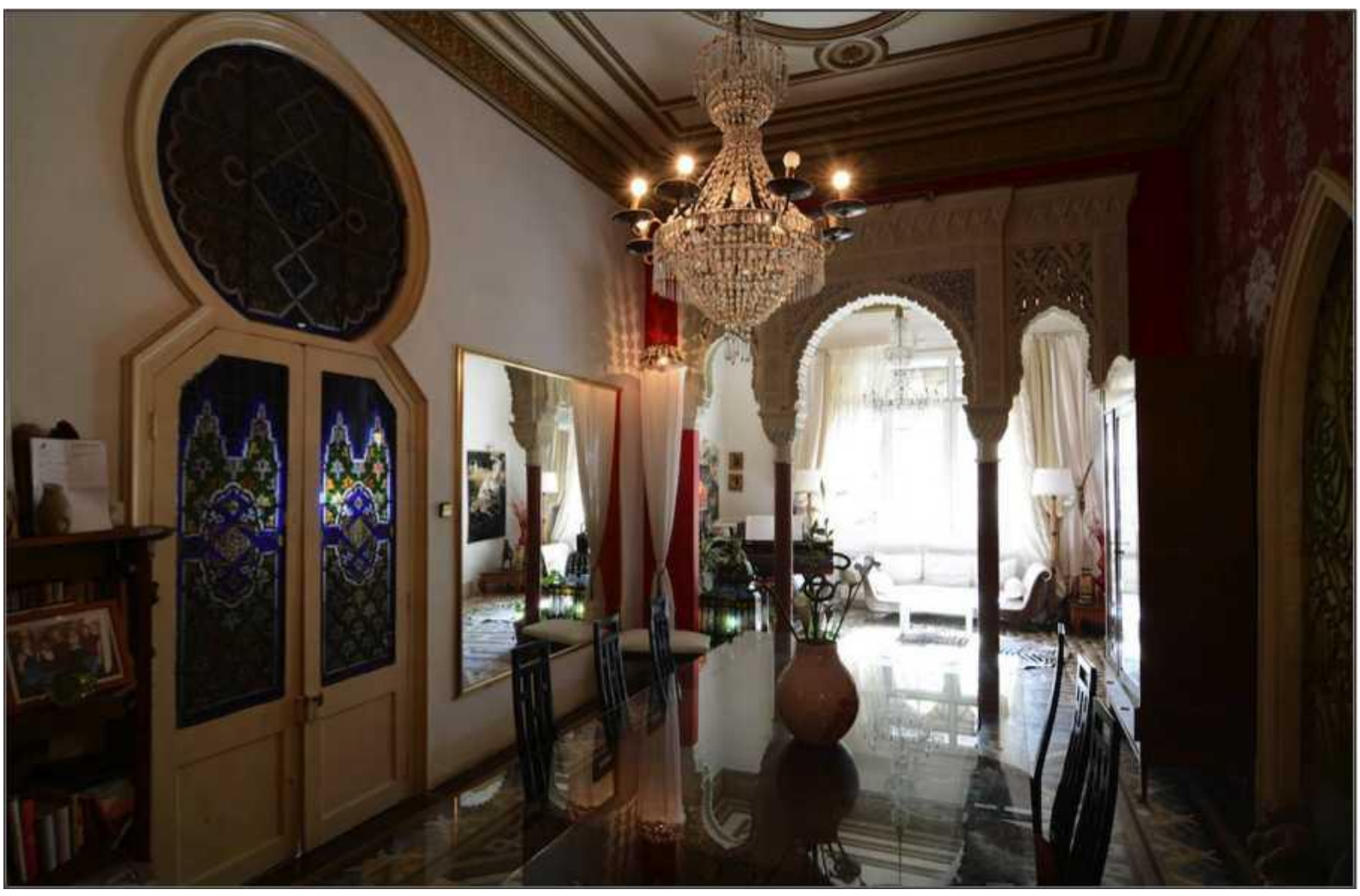

Fig. 11. Comedor de la Villa Hispanoárabe en la actualidad (2014) C Consol Bancells

La misma imagen antigua nos revela que en los ventanales de esta salita, actualmente cubiertos por sencillos vidrios transparentes, había tres bellas vidrieras pre-modernistas cuyo taller no hemos podido identificar. Por sus atributos (máscaras, instrumentos musicales y presencia de la vid), probablemente representaban alegorías de la danza y el teatro.

De todas ellas sólo se conserva una, que en algún momento fue trasladada al dormitorio que se encuentra junto a la entrada. Consiste en una figura femenina de proporciones escultóricas que nos recuerda a las sibilas miguelangelescas, y que aparece de espaldas, encaramada a una cepa de la que se dispone a coger un racimo de uvas. Va vestida a la manera clásica, con una túnica que deja parte de su espalda al descubierto y su posición nos revela su bello perfil (fig.12). De la cepa cuelgan una máscara teatral y dos instrumentos musicales, uno de los cuales parece un tympanum, símbolo de la locura dionisiaca, que solía ser tocado por mujeres, aunque la actitud comedida de estas musas hace que no podamos identificarlas con ménades ${ }^{47}$. 


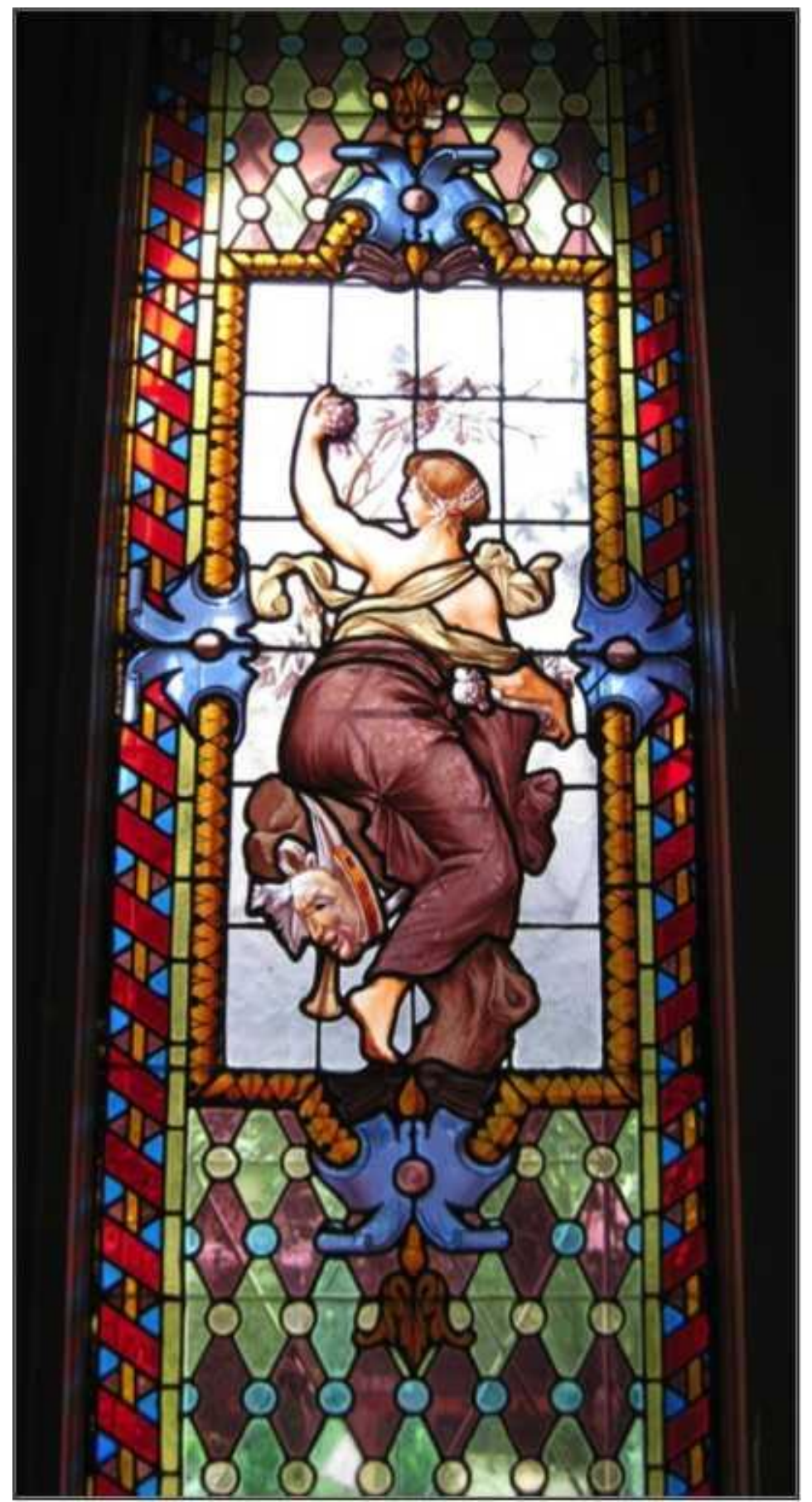

Fig. 12. Vidriera en la que aparece representada una musa teatral (2014) C Consol Bancells

Sin duda estas vidrieras, junto con las de las puertas de entrada al comedor de motivos arabizantes, conferirían a la estancia una atmósfera lumínica especial, de luz coloreada y vibrante. El hecho de que hubiera tres vidrieras con una iconografía relacionada con las artes escénicas podría deberse a que los promotores de la casa estuvieran profesionalmente vinculados al mundo del teatro o a que sintieran una especial inclinación por este arte, información que no hemos podido contrastar ${ }^{48}$. No obstante, su presencia no es extraña, pues una de las formas de ocio más extendidas en los hogares de prestigio desde 
finales del siglo XVIII y que a finales del XIX continuaba muy en boga, era la de celebrar veladas teatrales en los domicilios privados, los llamados "teatros de sala y alcoba" 49 .

La fotografía de 1909 nos permite inferir con bastante claridad dónde se llevarían a cabo las representaciones. Así, el arco carpanel sobre columnas que actuaba de transición entre el salón y la salita funcionaría como embocadura, contando incluso con los dos cortinajes que harían la función de telón, la salita constituiría la escena y, muy probablemente, los invitados se sentarían en sillas distribuidas a lo largo del salón comedor ${ }^{50}$.

De esta salita, además de la vidriera desplazada, también se conserva el pavimento de gres cerámico, cuyo diseño consiste en un laberinto de esvásticas que genera un efecto óptico tridimensional, muy de moda en aquella época pero que, al mismo tiempo, se recomendaba no emplear por la gran inestabilidad visual que generaba.

A pesar de que no se conserva ninguna documentación o factura en la que se especifique el fabricante, por sus características sabemos que los pavimentos comentados fueron fabricados por la casa Nolla. Además, hemos podido comprobar que algunos de los diseños de las estancias coinciden con los de esta fábrica, tal y como se desprende del catálogo (fig. 13) y de algunas de las piezas empleadas, que son características de esta empresa, como la olambrilla blanca con una cruz azul que aparece en el pavimento de la entrada. La casa Nolla era la fábrica especializada en mosaico de gres cerámico más importante de su sector, hasta el punto que los pavimentos de este tipo se conocían popularmente con el nombre de "pavimentos Nolla"51. Era la principal proveedora de las casas burguesas de solera junto con otras como la de Isidre Llevat, de Reus, o la Casa Tarrés, de Barcelona. Este tipo de suelos se popularizó en las últimas décadas del siglo XIX otorgándole los valores formales y cualitativos que anteriormente se daban a las alfombras, buscando trascender la estricta funcionalidad $\mathrm{y}$ proporcionar belleza y suntuosidad. Por su precio y arduo trabajo de instalación y mantenimiento se reservaban para las salas más nobles. Se realizaban a base de pequeñas teselas monocromas no superiores a los $10 \mathrm{~cm}$ de lado, cuya combinación generaba dibujos geométricos de una gran riqueza plástica. En la Villa Hispanoárabe además de en el recibidor, el salón comedor y la salita auxiliar, también se hallaban presentes en los dormitorios principales de la planta baja. A mediados de la primera década del siglo XX este tipo de pavimento fue perdiendo peso por el uso generalizado de mosaico hidráulico, de colocación más sencilla que el mosaico de gres.

Gracias a la mencionada revista Arquitectura y construcción ${ }^{52}$, también conocemos la identidad del taller que llevó a cabo la construcción de las yeserías del patio y, muy probablemente, de los cielos rasos de toda la casa. Se trata de Cosme Maurell de Pera, cabeza de un importante taller de la época que se dedicaba a la elaboración de yeserías decorativas ${ }^{53}$. 


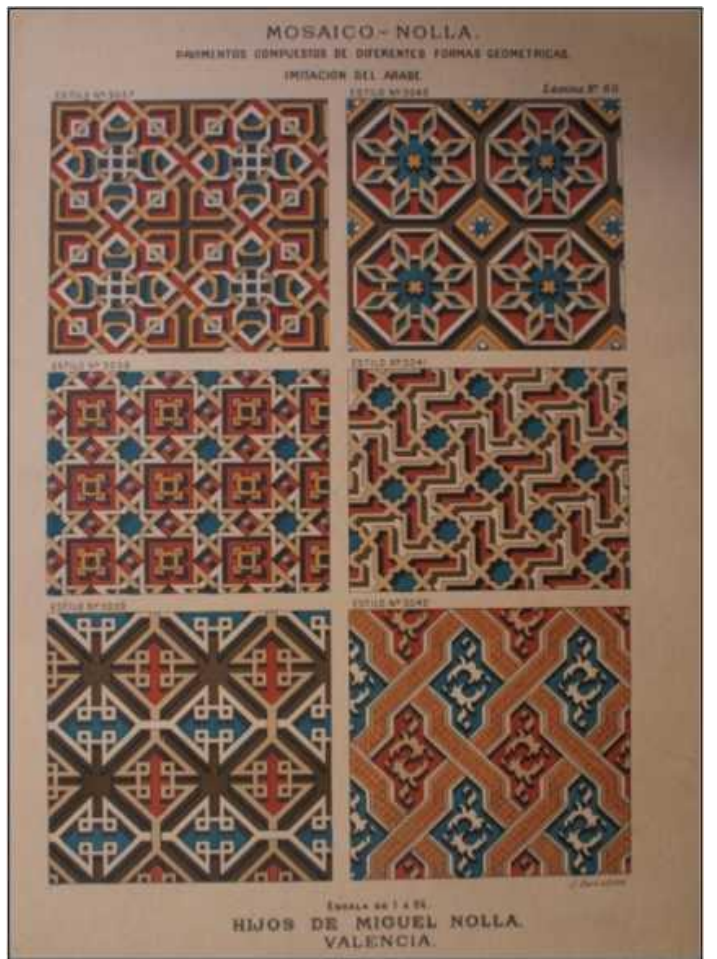

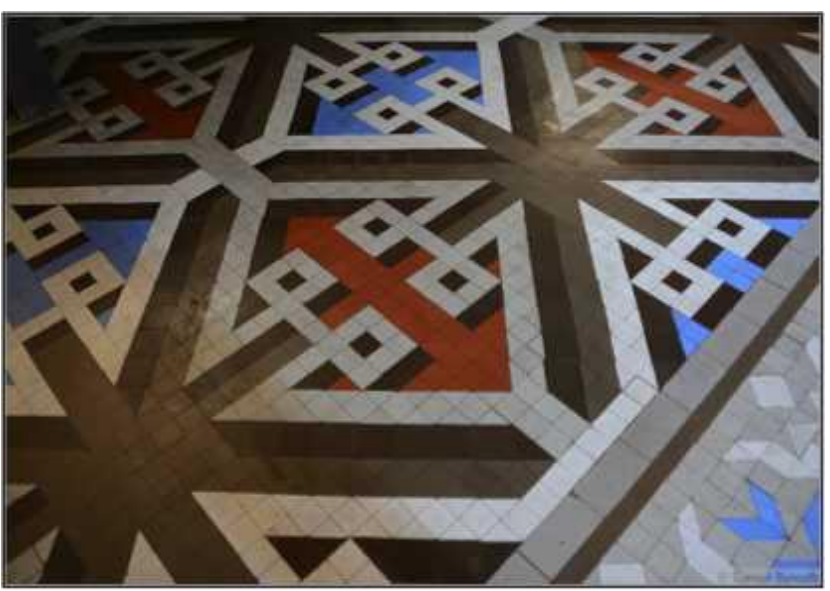

Fig. 13. Página del catálogo Nueva Industria Española. Hijos de Miguel Nolla, 1890 identificada como "Pavimentos compuestos de diferentes formas geométricas. Imitación del árabe". En el extremo inferior izquierdo se halla el diseño del mosaico del salón de la Villa Hispanoárabe (estilo $\mathrm{N}^{\mathrm{o}}$ 3039). Fuente: Archivo de Salvador Escrivá.

Fig. 14. Fotografía del pavimento del salón de la Villa Hispanoárabe (2014) C) Consol Bancells.

Tanto el patio como el salón comedor que hemos descrito en las páginas previas son las únicas estancias que han preservado sus elementos ornamentales originales prácticamente intactos $\mathrm{y}$, por tanto, son los espacios que nos ha interesado describir. El resto de las habitaciones de la casa han sido reformadas y únicamente conservan los cielos rasos y los pavimentos, algunos de ellos de mosaico hidráulico, como el que observamos en la fotografía en la que aparece retratado el matrimonio Dupont Farré (fig.1); o el de cerámica cocida del dormitorio del piso superior, cuya estética actual es también neoárabe, pero casi con total seguridad es fruto de una reforma posterior a la época en la que vivió Dupont, pues entonces ese espacio estaba posiblemente ocupado por las habitaciones de servicio, como ya hemos apuntado previamente. Es testimonio de ello el mencionado suelo, más pobre que en el resto de las estancias, y la falta de amplios ventanales, penetrando la luz únicamente por pequeñas oberturas.

La Villa Hispanoárabe está catalogada dentro del plan especial de protección del patrimonio arquitectónico histórico-artístico de la ciudad de Barcelona y, como hemos podido observar, a diferencia de otras construcciones del mismo estilo, cuyo uso ha variado con el paso de los años, ha conservado su función residencial originaria, y es por ello que hasta la presente investigación sus destacados interiores permanecían inéditos.

En la actualidad luce con todo su esplendor, pues sus actuales propietarios, conscientes de su valor patrimonial, llevaron a cabo la restauración de sus partes principales cuando la compraron ${ }^{54}$. 


\title{
NOTAS
}

\begin{abstract}
${ }^{1}$ Véase: BELTRÁN, C., Celestino Dupont (1859-1940) y el comercio de antigüedades en Cataluña: de la esfera privada al ámbito internacional. Trabajo de fin de máster. Barcelona: Universidad de Barcelona, 2014.

${ }^{2}$ Quiero manifestar mis más profundos agradecimientos a K. L. y R. G. por abrirme las puertas de su casa y atenderme siempre con tanto cariño, y a la fotógrafa Consol Bancells por la cesión de las fabulosas fotografías que nos permiten ilustrar el texto y estudiar la transformación experimentada por los interiores a lo largo de los
\end{abstract} años.

${ }^{3}$ Para una aproximación a la historia de Sant Gervasi de Cassoles vid. PORTAVELLA ISIDORO, J., Els Carrers de Barcelona: Sant Gervasi. Barcelona: Ajuntament de Barcelona, Arxiu Municipal, Districte de Sarrià-Sant Gervasi, 2010, pp. 13-27.

${ }^{4}$ PERMANYER, LL., "El Frare Blanc se salva de la ruina”, La Vanguardia, 16 de mayo de 1988, p.6.

${ }^{5}$ Cf. PORTAVElla, J., Els Carrers de Barcelona: Sant Gervasi. Barcelona: Ajuntament de Barcelona, Arxiu Municipal, Districte de Sarrià-Sant Gervasi, 2010, p. 19.

${ }^{6}$ Cf. Ibid., pp. 19-21.

${ }^{7}$ El arquitecto firmó los planos adjuntos a la solicitud de permiso de obras el 21 de agosto de 1893. Fuente: AMDSG-FO- 3474-1893. En el momento de su construcción la calle se llamaba Frare Blanc y la casa se hallaba en el número 25. Una vez la calle cambió su nombre por el de Leon XIII en 1895, se mantuvo dicha numeración durante unos años, hasta que cambió por el número 15, que continúa en el presente.

${ }^{8}$ El Comité directivo de la Sociedad estaba integrado por destacados prohombres de la ciudad: el mencionado Salvador Andreu, que ostentaba el cargo de Presidente; Romà Macaya (c.1843-1923) y Teodor Roviralta (c.1854-1920), de Directores; Ròmul Bosch (1852-1923), de Presidente del consejo de Administración; Josep Garí (1854-1925), de Vicepresidente; Joan Adolf Mas (1850-1943), de Secretario; y Francesc Simón (18431923), Antoni Gassol, Josep Maria Florensa (1848-1926) y Joaquim Cabot (1861-1951), de Vocales. Otro miembro destacado de la Sociedad fue Manuel Arnús (1852-1916), que le dio el empuje económico decisivo que necesitaba para arrancar, pues inicialmente costaba encontrar accionistas que creyeran en el proyecto. La mayoría de estos personajes tienen hoy en día una calle consagrada a su figura en los aledaños de este territorio que contribuyeron a urbanizar.

${ }^{9}$ El revival neoárabe, también llamado neomusulmán, neoislámico o neoalhambrista (en honor a la Alhambra de Granada), consiste en una lectura desde el prisma ecléctico de la arquitectura del Islam, con especial referencia a la arquitectura árabe realizada en España durante el periodo medieval (Cf. HERNÁNDEZ, S., Arquitectura para la ciudad burguesa. Canarias, siglo XIX. Islas Canarias: Gobierno de Canarias, Consejería de Educación, Universidades, Cultura y Deportes, 2009, pp. 137-138). Para un análisis más completo del concepto neoárabe vid. RODRÍGUEZ, J.M.,"Neomudéjar versus Neomusulmán: definición y concepción del medievalismo islámico en España”, Espacio, tiempo y forma. Serie VII, Historia del arte, núm. 12, 1999, pp. 265-286.

${ }^{10}$ Tal y como señala Federico Revilla "La parte septentrional de Cataluña fue sólo musulmana durante unos pocos decenios y seguidamente modeló a su propia imagen, que era más bien postvisigoda y carolingia, la Cataluña nueva que se fue conquistando a expensas del Islam" (REVILLA, F., "Otras precisiones sobre la arquitectura neomusulmana en Cataluña". En: Boletín del Seminario de Estudios de Arte y Arqueología, Vol. L, 1984, p. 392).

${ }^{11}$ Cf. Ibid., p. 391.

${ }^{12}$ Para más información vid. BONET, A., "El estilo neoárabe en España”. En: MOZZONI, L.; SANTINI, S., [coords.], Architettura Dell'Eclettismo. La Dimensione Mondiale. Nápoles: Liguori Editore, 2006, pp. 47-90; LITVAK, L., "Exotismo del Oriente musulmán fin de siglo", Awraq: Estudios sobre el mundo árabe e islámico contemporáneo, núm. Extra 1, (Ejemplar dedicado a: Africanismo y Orientalismo Español), 1990, pp. 73-103.

${ }^{13}$ Citado en: BRU, R., Orient-Bcn. Guia d'Història Urbana. Barcelona: MUHBA, Ajuntament de Barcelona, Institut de Cultura de Barcelona, 2011 [folleto]. Disponible en línea:

[http://w110.bcn.cat/fitxers/icub/museuhistoria/guiaorientbcn.318.pdf]. Consulta: 02/10/2014.

${ }^{14}$ Fortuny fue comisionado por la Diputación de Barcelona para inmortalizar el acontecimiento bélico. El mundo musulmán cambió su manera de pintar, experimentando una renovación estética que lo situó a medio camino entre la corriente romántica en la que se había formado y el Realismo que comenzaba a imponerse. En esa época 
realizó varios viajes a Marruecos y también pasó dos años en Andalucía (1870-1872), estancias que contribuyeron a despertar el interés de los artistas y literatos catalanes por desplazarse allí a crear, como Josep Tapiró, Ricard Canals o Santiago Rusiñol, y que le consagraron como el gran pintor orientalista, responsable de introducir esta corriente en Cataluña a través de sus lienzos. Para más información vid. ALCOLEA, Op. Cit., 1988, p. 30; FONTBONA, F., "Africanismo y Orientalismo en la renovación de la pintura catalana moderna", Awraq: Estudios sobre el mundo árabe e islámico contemporáneo, núm. Extra 1 (Ejemplar dedicado a: Africanismo y Orientalismo Español), 1990, pp. 105-127.

${ }^{15}$ Se emprenderán numerosas construcciones siguiendo el revival orientalista, tanto neoárabe como neomudéjar. Lo encontramos en casas y palacetes particulares de la burguesía (casa Marsans, en el paseo Mare de Dèu del Coll, obra de Juli Marial; casa Pere Llibre, en Paseo de Gracia, obra de Domènec Balet; el Edificio Alhambra, en la calle Berlinés, también de Domènec Balet; la Casa de las Alturas, en la Ronda Guinardó, edificada por Enric Figueras, etc.). También hay ejemplos de establecimientos comerciales, la mayoría desaparecidos (el Hotel Restaurante Tibidabo, la sala de música del Hotel Colón, el colmado "La Tropical", etc.), o de uso público (la desaparecida Torre Laribal, que fue sede de la escuela del Bosc; el "Xalet del Moro", etc.) Igualmente esta moda se extendió a los lugares de veraneo de la burguesía, como por ejemplo en Sant Cugat del Vallès, donde hoy en día se conserva la casa "El Generalife", construida por Eduard Maria Balcells en 1912 por encargo de Justo Sánchez, con motivos decorativos inspirados en la Alhambra y el Generalife; en el Arboç del Penedès, donde el fotógrafo aficionado Joan Roquer Marí encargó al maestro de obras Anton Feliu levantar un palacete con una réplica de la Giralda y en cuyo interior reprodujo el Patio de los Leones de la Alhambra y el Salón de los Embajadores del Alcázar de Sevilla, etc. Para más información sobre los edificios neoárabes en Barcelona vid. BRU, Op.cit.; RODRÍGUEZ, J. M., La Arquitectura “neoárabe” en España: el medievalismo islámico en la cultura arquitectónica española, 1840-1930. Tesis doctoral. Granada: Universidad de Granada, 1997.

16 Para más información vid. REVILLA, F., "Una interpretación psicosociológica de la arquitectura neomusulmana en Cataluña”, Revista de ideas estéticas, núm. 126, 1974, pp. 37-44.

${ }^{17}$ Cf. LITVAK, Op. cit., pp. 74-103.

${ }^{18}$ Esta información ha sido proporcionada por la actual propietaria de la finca, que señala que en el momento de adquirir la casa el agente inmobiliario le explicó que en ella había vivido un sultán, y que hoy en día es una creencia generalizada de la gente mayor del barrio.

${ }^{19}$ RODRÍGUEZ, Op. cit., 1999, p. 276.

${ }^{20}$ Las yeserías se reproducían a través del método de la galvanoplastia, que consistía en "sobreponer una capa de un metal disuelto en líquido a un modelo sólido, y valiéndose de la aplicación de corrientes eléctricas se obtenían moldes para vaciados. El restaurador de la Alhambra [Rafael Contreras Muñoz] pronto adoptó este sistema en su taller de reproducciones artísticas. Antes de la utilización del método galvanoplástico, los vaciados se ejecutaban con el sistema de moldes elásticos, compuestos de suficiente número de piezas y madres-formas para no dañar los modelos al ser desprendidos" (RODRÍGUEZ, J. M., "La Alhambra efímera: el pabellón de España en la Exposición Universal de Bruselas (1910)". En: Cuadernos de arte de la Universidad de Granada, núm. 28, 1997, p.133).

${ }^{21}$ Citado en: BARRIOS, J. M., "José Contreras: un pionero de la arquitectura neoárabe: sus trabajos en la Alhambra y la Alcaicería”. En: GONZÁLEZ, J. A., La invención del estilo hispano-magrebí. Presente y futuro del pasado. Barcelona, Rubí: Anthropos, 2010, p. 284.

${ }^{22}$ Cf. REVILLA, Op. cit., 1984, p. 393.

${ }^{23}$ Hijo de Jacinto Vega Cornejo, ayudante de la Sección de Obras Públicas de la Diputación de Barcelona. Como arquitecto trabajó sobre todo en las Islas Canarias y en diversos países de América del Sur, y en Barcelona se conoce poca obra suya. Fue, a su vez, secretario del Montepío Protector de los Obreros de la Edificación de Barcelona en 1899, profesor de la Escuela de Arquitectura, director de la Escuela de Bellas Artes entre 1921 y 1931, impulsor de la Asamblea de Profesores de Escuelas Industriales y de Artes y Oficios en 1922, y presidente de la Asociación de Arquitectos de Cataluña, en 1930. Dirigió desde 1896 la Revista de la Asociación de Arquitectos de Cataluña, a la que otorgó una periodicidad quincenal, y en cuyas páginas insertó por primera vez publicidad. Pronto la sustituyó por la publicación de Arquitectura y construcción, primera revista privada de arquitectura de Cataluña. Perteneció, a su vez, a la Academia Catalana de Bellas Artes de San Jordi y de San Fernando y fue vocal de la Junta de Museos de Barcelona. Escribió numerosos artículos y participó en varios congresos. (Cf. CAÑELLAS, C.; TORAN, R., Els governs de la ciutat de Barcelona (1875-1930): eleccions, partits i regidors: diccionari biogràfic. Barcelona: Ajuntament de Barcelona, 2013, p. 207).

${ }^{24}$ La actitud "más libre" de Vega i March fue la seguida por la mayoría de los arquitectos que afrontaron las 
construcciones neoárabes: “[...] partiendo de un antiacademicismo radical y de un incontestable rechazo a la noción de estilos históricos, recurrieron sin embargo a las fuentes primigenias para elaborar un nuevo lenguaje a partir de una selección y traslación de elementos muy diversos, y de dispares procedencias, para recombinarlos y articularlos en una nueva formulación" (GARCIA, M., "Paradisos artificials". En: CARBONELL, S. y CASAMARTINA, J., (coord.), Miralls d'Orient. Terrassa: Centre de Documentació i Museu Tèxtil, 2004, p. 208).

${ }^{25}$ El patio en las viviendas de Al-Andalus (en árabe wast al-dar, que significa centro de la casa) era el eje de la vida familiar. Su función era la de comunicar, iluminar y ventilar todas las habitaciones de la vivienda, y su disposición hacía posible limitar al mínimo los vanos en el exterior. En él estaba presente el agua en forma de estanque, fuente o pozo y, por pequeño que fuera, siempre había espacio para flores y plantas. Cf. ORIHUELA, A., "La casa andalusí: un recorrido a través de su evolución", Artigrama: Revista del Departamento de Historia del Arte de la Universidad de Zaragoza, núm. 22, 2007, p. 301.

${ }^{26}$ Información sobre su fallecimiento en La Vanguardia, 11 de noviembre de 1898, p.2.

${ }^{27}$ En la documentación relativa a la finca conservada en el Registro de la Propiedad Urbana de Barcelona (RPUB) se especifica, igualmente, que en esa fecha la casa ya había sido construida, por tanto, podemos estimar que las obras se acometieron entre 1893 y 1899. Fuente: RPUB núm. 12, finca 2847.

${ }^{28}$ Información sobre su fallecimiento en La Vanguardia, 6 de diciembre de 1899, p.2.

${ }^{29}$ En la documentación figura como propietaria Josefa Farré, asistida por su marido Celestino Dupont. Fuente: RPUB, núm. 12, finca 6333.

${ }^{30}$ Cf. GARCIA, A., [et.al], Cent anys de la Junta de Museos a Catalunya. 1907-2007. Barcelona: Publicacions de l'Abadia de Montserrat, 2008, pp. 29, 41.

${ }^{31}$ Fuente: AMCB FO-531/1908.

${ }^{32}$ Fuente: AMCB FO-644/1910.

${ }^{33}$ Fuente: RPUB núm. 12, finca 6333. A pesar de que hoy en día es un gran desconocido, el pintor Ramón López Morelló gozó de cierto reconocimiento en su época, a juzgar por los comentarios de la prensa histórica, que se refieren a él con los adjetivos de "afamado" o "conocido" (La Vanguardia, 29 de mayo de 1923; La Vanguardia, 5 de diciembre de 1923). En 1932 expuso la obra Mare i filla en la exposición de primavera del Salón de Montjuic, y por aquel entonces residía en la calle Rosselló 156 (Cf. Exposició de Primavera 1932: Saló de Montjuïc: Parc de Montjuïc, 22 maig- 3 juliol. Barcelona: Junta Municipal d'Exposicions d'Art, 1932.) Igualmente, su nombre aparece en varias ocasiones en la prensa madrileña, en la que se le suele calificar como un pintor decorativista. Siendo muy joven fue premiado en un concurso de dibujos sobre Don Quijote organizado por El Heraldo de Madrid (Cf. Mundo Gráfico, 5 de julio de 1916, p. 9). En ocasiones la prensa muestra alguna de sus obras, como es el caso del dibujo Ironía eterna expuesta en el Tercer Salón de los Humoristas (La Esfera: ilustración mundial, Año IV, núm. 161, 27 de enero de 1917, p. 17); y también habla de sus exposiciones, como su muestra monográfica de dibujos que tuvo lugar en el "Salón Lacoste" en 1916, siendo jovencísimo ( $L a$ Esfera: ilustración mundial, Año III, núm. 126, 27 de mayo de 1916, p. 28; La Acción, 15 de mayo de 1916, p.1; La Época, 21 de mayo de 1916, p.3); o su participación en la exposición colectiva de dibujos de artistas españoles celebrada en los almacenes barceloneses "El Siglo", en 1923 (La Esfera: ilustración mundial, Año X, Número 515, 17 de noviembre de 1923, p.19). Una crítica a su obra por parte de Joaquín Ciervo puede leerse, a su vez, en este diario (La Esfera: ilustración mundial: Año XI núm. 539, 3 de mayo de1924, p.24). También tenemos noticia de una exposición monográfica de sus pinturas celebrada en Jaén que glosan el famoso poema Sonatina de Rubén Darío (El Sol, 12 de agosto de 1917, p. 5).

${ }^{34}$ Desconocemos qué hizo Dupont con la parte de la finca segregada en la que se hallaba situado el espacio que albergaba su negocio. Probablemente también lo vendió algunos años después de su traslado a Sevilla, al igual que hizo con la Villa Hispanoárabe, pues en 1941 figura como propietaria la señora Magdalena Juanola Gifra. En aquellos momentos dicho espacio ya había sido adaptado como vivienda, y la propietaria solicitó un permiso para efectuar obras de ampliación que consistieron en la adición de una planta encima de la construcción preexistente, para cuya coronación se reaprovechó la baranda, las tejas y la cornisa que originalmente remataban el cuerpo concebido por Font y Gumà. En 1949 se reformó la puerta del muro de cerca de la casa y se construyó un garaje. En la solicitud del permiso figura como propietario Magín Ricart Mayoral.34 En la actualidad esta casa es una residencia particular cuya entrada principal se halla en la calle Mas Yebra 8.

${ }^{35}$ La Vanguardia, 26 de julio de 1936.

${ }^{36}$ Fuente: AMCB-ANT-19489. 
${ }^{37}$ REVILLA, Op.cit., 1984, p. 394.

${ }^{38}$ Esta cupulilla es muy similar a la que a finales de los años cincuenta del siglo XIX cubría el pabellón oriental del Patio de los Leones de la Alhambra, y que no era la original del palacio nazarí, sino una reinterpretación elaborada por Rafael Contreras. Desde entonces esta "falsa cúpula" del patio alhambrista se reprodujo en numerosísimas construcciones neoárabes, siendo un ejemplo la Villa Hispanoárabe, lo que la acabó por convertir en "verdadera", según señaló el que fue el arquitecto y conservador de la Alhambra entre 1923 y 1936, Leopoldo Torres Balbás, que en 1935 decidió demolerla y restaurar la cubierta original.

${ }^{39}$ Mensaque, Rodríguez y Cía. S.A., Catálogo de azulejos de serie. Sevilla: [s.f.]

${ }^{40}$ Cf. MÜNZER, J., Viaje por España y Portugal (1494-1495). Madrid: Polifemo, 1991, pp. 93-97. Su testimonio y el de otros visitantes condujo a que el Patronato de la Alhambra decidiera su recuperación en una reciente restauración concluida en el año 2012.

${ }^{41}$ Owen Jones estuvo en la Alhambra junto con el arquitecto francés Jules Goury en 1834. Permanecieron seis meses en el transcurso de los cuales Goury murió a consecuencia de la epidemia de cólera que asoló la ciudad. En 1837 Owen Jones regresó, y con el material reunido trabajó varios años empleando la novedosa técnica de la cromolitografía, que le permitió reproducir la policromía original. Durante su minucioso estudio de la Alhambra, llevó a cabo dibujos, alzados e incluso calcos y vaciados en yeso, que plasmó en las láminas de su célebre Plans, Sections, Elevations and Details of the Alhambra (1842-1845), donde también desarrolló su teoría del color. De esta forma, Jones proporcionó una nueva visión del monumento granadino lejos de la visión romántica, estudiándolo como un auténtico tratado de arquitectura, en el que era posible investigar la ciencia exacta del ornamento y del color, cuyas leyes trataban de hallar por aquel entonces los arquitectos contemporáneos. Para más información sobre Owen Jones Jones y sobre el papel desempeñado por la Alhambra en las reflexiones de numerosos artistas y arquitectos contemporáneos vid. CALATRAVA (et.al) [comis.]. Owen Jones y la Alhambra. Granada: Patronato de la Alhambra y Generalife, Consejería de Cultura, Junta de Andalucía; Londres: V\&A Victoria and Albert Museum, 2011.

${ }^{42}$ Cf. La Ilustració Catalana, 20 de junio de 1909, p.12.

${ }^{43}$ Cf. Arquitectura y construcción, núm. 109, 8 de septiembre de 1901, pp. 266-267.

${ }^{44}$ Cf. La Ilustració Catalana, 20 de junio de 1909, p.12.

${ }^{45}$ RODRÍGUEZ, L., "Los talleres de ebanistería de Barcelona (1875-1914)”, Estudi del moble, núm. 14, 2011, p. 27.

${ }^{46}$ No hemos hallado documentación que nos indique en qué momento se llevó a cabo la reforma, aunque con toda seguridad es posterior a la Guerra Civil.

${ }^{47}$ Las ménades eran sacerdotisas de Baco que en la celebración de los misterios daban muestras de frenesí. Fuente: Diccionario de la RAE [http://lema.rae.es/drae/?val=m\%C3\%A9nade]. Consulta: 28/09/2014.

${ }^{48}$ Curiosamente, en el caso de la familia Dupont esta iconografía encajaba a la perfección, pues el hijo homónimo de Celestino era, como hemos visto, un joven escritor de piezas teatrales, lo que nos conduce a pensar que quizás estas vidrieras se instalaron posteriormente, cuando los Dupont compraron la casa, aunque tan sólo es una hipótesis.

${ }^{49}$ Se tiene constancia de representaciones teatrales en las casas particulares de Felip Nadal, en Sarrià; en el palacio de los duques de Alba y marqueses de los Vélez; el barón de Maldà, de la calle del Pi; Jeroni Borràs, en la misma calle; Vives, en la calle Canuda; barones de Rocafort, en la Rambla, Sanjuan, en la Riera de Sant Joan; Tarancó; etc. (Cf. CURET, F., Teatres particulars a Barcelona en el segle XVIII. Barcelona: Generalitat de Catalunya. Publicacions de la Institució del Teatre, 1935, p. 60). En estos espectáculos muchas veces se representaban grandes obras adaptándolas al pequeño formato, con reducido número de personajes, y también había piezas escritas por autores generalmente locales, siendo los sainetes y comedias los géneros más habituales. Lamentablemente, a pesar de que era un pasatiempo muy habitual, se conservan pocos documentos, pues la propia naturaleza privada de estos eventos, a los que se accedía por estricta invitación, hacía que tuvieran poco eco en la prensa escrita. Solían producirse en días señalados para la familia anfitriona y eran un pretexto para invitar a la familia y amistades. Los propios miembros de la familia eran muchas veces los actores de la comedia o el drama, aunque también se podía contratar a actores profesionales, y la celebración daba lugar a la ostentación de los recursos económicos de la familia a través de la confección del vestuario, la exhibición del mobiliario, etc. (Cf. FÀBREGAS, X., Les formes de diversió en la societat catalana romántica. Barcelona: Curial, 1975, pp.70-75; RUIZ, N., Els teatres particulars a Barcelona en el segle XVIII. El teatre representat en els espais domèstics. Trabajo de fin de Máster. Barcelona: Universitat de Barcelona, 2010). 
${ }^{50}$ Estos espectáculos no sólo permitirían a Dupont Farré promocionarse como autor teatral, sino que también serían una excusa para que su padre pudiera mostrar las obras de arte que inundaban la casa, así como cerrar negocios de compraventa con los selectos invitados, entre los que, con toda probabilidad, abundarían los coleccionistas.

${ }^{51}$ Fábrica valenciana fundada por Miquel Nolla i Bruixet (1815-1879) y continuada después por sus hijos, Miquel y Lluís. Fue la introductora de la técnica en España y responsable, a su vez, de su expansión y comercialización. Para más información vid. REIG, A. M.; ESPÍ, A., "La aplicación del diseño a la industria del mosaico valenciano del siglo XIX: Nolla y Piñón”, Archivo de arte valenciano, Vol. XCI, 2010, pp. 13-37; NAVAS, T., La casa Escofet de Mosaic Hidràulic (1886-1936). Tesis de Licenciatura. Barcelona: Universitat de Barcelona; ROSSELLÓ, M., "Revestiments per als interiors de l'arquitectura. Algunes aportacions de la indústria”, Congrés d'Història de Barcelona. Dilemes de la fi de segle, 1874-1901, Arxiu Històric de la Ciutat de Barcelona, Institut de Cultura, Ajuntament de Barcelona, 27-30 de Noviembre, 2007, pp. 58-59; ROSELLÓ, M., La casa Escofet: mosaics per als interiors 1886-1900-1916. Barcelona: Escofet, 2009.

${ }^{52} \mathrm{Cf}$. Arquitectura y construcción, Op. Cit.

${ }^{53}$ Tenía su taller en la calle Diagonal 223, y a partir de 1908 en la calle Gerona 153. Su hermano Bartolomé Maurell también era decorador, especialista en piedra artificial e incrustaciones de mármol, con taller en la calle Bruc 192. A pesar de ser hoy en día un gran desconocido, Cosme Maurell llevó a cabo las yeserías de emblemáticas arquitecturas del ocio del periodo tales como el Café Novedades (1904), el Café Restaurante de la Exposición Universal (1888), el Café Restaurante de la Maison Dorée (1903), el Café las Delicias (1886), etc. (Cf. LÓPEZ, F., Ornamentació vegetal i arquitectures de l'oci a la Barcelona de 1900. Tesis doctoral. Barcelona: Departament d'Història de l'Art, 2013, pp. 1168, 1178, 1187. Disponible en línea: [http://www.tdx.cat/handle/10803/96770]. Consulta: 02/09/2014. También participó en otras construcciones, por ejemplo, en la decoración en 1899 del Salón de Sesiones de la Casa Consistorial de Sitges (Cf. MARTÍ, J. L., [ed.], El Doctor Robert. Barcelona: Fundació Uriach 1838, 2004, p. 22); en el techo del salón de Actos de la Asociación de Arquitectos de Cataluña, en 1893-1894 (Cf. Anuario de la Asociación de Arquitectos de Cataluña. Barcelona: Henrich i Cía, 1900, s.p.); en el Palacio de Bellas Artes y el Pabellón Regio de la Exposición Universal de Barcelona (1888) (Cf. Catálogo oficial especial España, 1888. Barcelona: Imprenta de los sucesores de N. Ramírez y Cía, 1888, p.103). Trabajó a las órdenes de los principales arquitectos del momento, como Domènech i Montaner o August Font. Este último, en 1893 fue el encargado de proyectar su casa en la avenida Diagonal, cuyo proyecto y planos se conservan actualmente en el Archivo del Colegio de Arquitectos de Barcelona (AHCOAC H 102C/6/3066; AHCOAC C 240/9).

${ }^{54}$ Recientemente, el taller de vidrieras barcelonés J.M Bonet (C/Asturias, 6), responsable de la confección de vidrieras para obras cumbre, como las del ábside de la Sagrada Familia, ha restaurado las vidrieras del patio.

Fecha de recepción: 15 de octubre de 2014

Fecha de revisión: 11 de noviembre de 2014

Fecha de aceptación: 17 de noviembre de 2014 